\title{
MEASUREMENT AND NUMERICAL SIMULATION OF TWO-PHASE PLASMA FLOW IN PLASMA SPRAY PROCESS *
}

\author{
V. Grigaitienè, V. Valinčius, and R. Kèželis \\ Lithuanian Energy Institute, Breslaujos 3, LT-35444 Kaunas, Lithuania \\ E-mail: vika@mail.lei.lt
}

Received 26 September 2008; revised 10 February 2009; accepted 19 March 2009

\begin{abstract}
Interaction of plasma jet with hard ceramic particles was numerically investigated by means of "Jets\&Poudres" software improved and applied to model a specific plasma jet. The data on free plasma jet, with injected dispersed particles, its temperature and velocity distribution, as well as particles' melting state are presented. It was found that dispersed particles achieve higher temperature and velocity values than plasma gas at dimensionless distance $x / d=8-12$ from exhaust nozzle. Numerical investigations were compared with experimental data. The results show that applied numerical model of two-phase high temperature jet calculation is in good agreement with experimental data and could be used to determine the optimal plasma spray parameters for coatings with desirable characteristics.
\end{abstract}

Keywords: plasma jet, plasma spraying, dispersed particles, coating synthesis

PACS: 68.47.Gh, 68.55.-a, 68.90.+g

\section{Introduction}

Atmospheric pressure plasma spraying is widely used to produce various coatings, especially hard ceramic coatings for wear and corrosion protection and thermal barrier function, porous catalytic coatings for environment control and protection, hydrophobic coatings, etc. The plasma spraying process uses a DC electric arc to generate a jet of high temperature ionized plasma gas, which acts as the spraying heat source. The sprayed material, in powder form, is carried into the plasma jet where it is heated, partially or fully melted and propelled towards the substrate. The properties of the produced coating are dependent on the feedstock material, the thermal spray process and application parameters, and post treatment of the coating. However, the influence of flow and particle temperature and velocity on coating characteristics, its adherence to the substrate, reproducibility of its properties, and quality is not clearly established [1]. Generally, to correlate coating properties to flow parameters and particle in-flight characteristics experimental procedure is used. To monitor the whole plasma spraying process (plasma jet generation, powder injection, formation of the coat-

\footnotetext{
* Results presented at the international conference Radiation Interaction with Material and Its Use in Technologies 2008, 24-27 September 2008, Kaunas, Lithuania
}

ing) the techniques such as plasma computer tomography (PCT), particle shape imaging (PST), particle flux imaging (PFI) [2] are used. Those techniques are expensive and complicated to use in industry. Numerical investigations of plasma spray process generally are focussed on investigation of heat transfer between plasma jet and surface [3], substrate temperature influence on coatings' morphology, adhesion, chemical processes between substrate material and deposited material $[4,5]$.

In this paper, by means of "Jets\&Poudres" software [6], a numerical simulation of interaction of plasma jet and dispersed particles was investigated. Simulation results were compared with experimental data.

\section{Methodology}

Numerical research of two-phase high temperature jet was carried out using "Jets\&Poudres" software [6], created on the basis of General Mixing (Genmix) software improved by using thermodynamic and transport properties closely related to the local temperature and composition of the plasma. For a particle in a plasma jet, two characteristics are studied: motion (trajectory, velocity) and thermal evolution (temperature, physical state, heat flux). Thermodynamic and transport properties of the gases are obtained from the T\&TWinner 


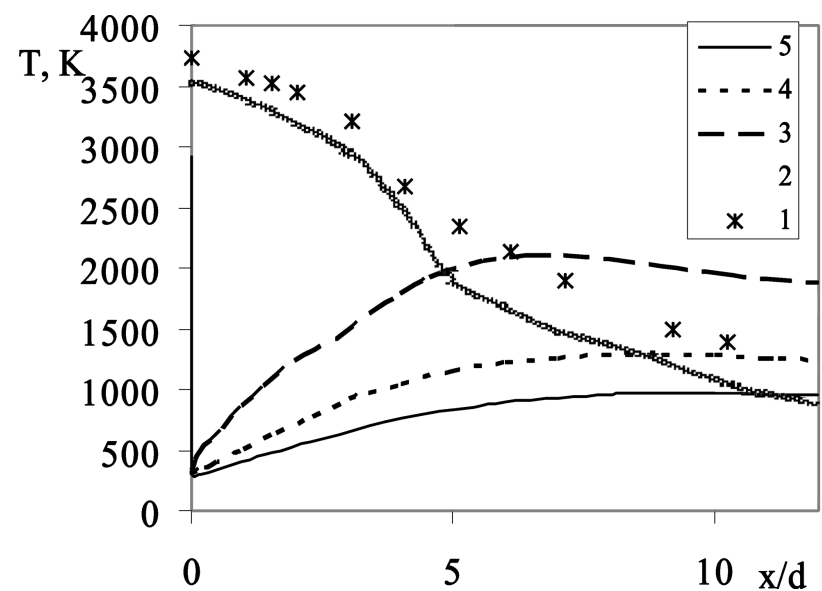

(a)

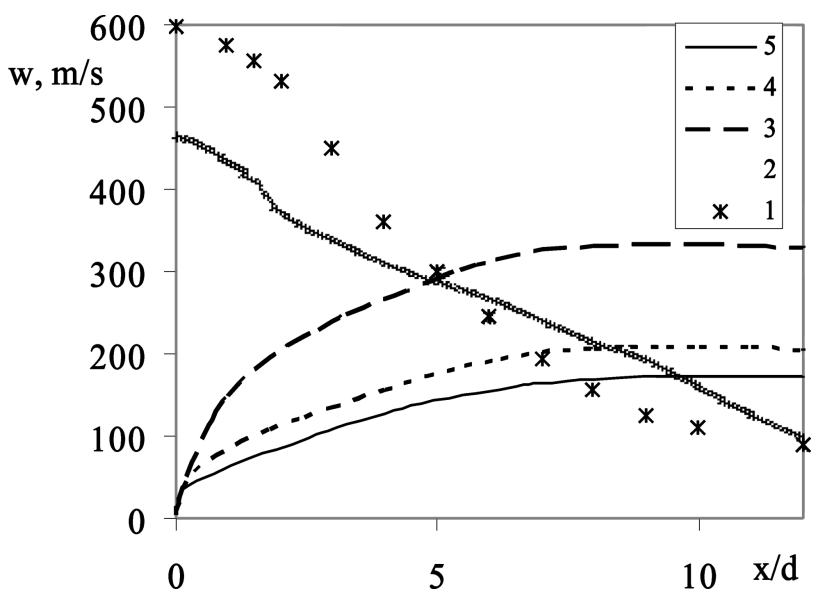

(b)

Fig. 1. (a) Distribution of temperatures and (b) velocities of $\mathrm{Al}_{2} \mathrm{O}_{3}$ particles and plasma jet determined by measurements along the spraying distance. 1, 2 show plasma jet experimental and numerical simulation results respectively; 3, 4, and 5 represent particles of 75, 50, and $35 \mu \mathrm{m}$ in diameter respectively. $x / d$ is a dimensionless distance.

database [7]. The coating material particle characteristics are also available as a database. Calculations are carried out for air plasma at atmospheric pressure flowing from jet reactor exhaust to substratum. When the parameters of plasma jet are achieved as desirable, hard spherical dispersed particles are injected into the flow. While modelling and calculating, the deformations of the plasma jet thermo fields are disregarded, inlet profiles of temperature and velocity are rectangular shaped and correspond to our estimated experimental data [8]. Plasma jet flows in one direction and the flow is stable, without recirculation and diffusion effects. The numerical simulation results have been compared with experimental data.

Experimental plasma spraying system [9] consists of linear DC plasma generator (PG) of $30-40 \mathrm{~kW}$ power with hot cathode and step-formed anode, plasmachemical reactor, systems of power supply and regulation, PG cooling, feeding, and dosing. The operational characteristics of plasma generator are presented in detailed analysis in [10].

During plasma spraying experiments the operating conditions of plasma torch were maintained constant. The capacity of plasma torch, total mass flow of air, cooling water, and its temperature were measured and from this data the plasma jet temperature was calculated (see Table 1). Injection of hydrogen was used to vary outlet plasma jet temperature and velocity, while plasma torch parameter was stable. Powder injection was provided into reactor, which was connected directly to plasma torch anode. Micrographs of the $\mathrm{Al}_{2} \mathrm{O}_{3}$ powder and sprayed films morphologies were collected using a scanning electron microscope and an optical microscope. Some separate sprayed particles were col-
Table 1. Plasma spraying regimes for $\mathrm{Al}_{2} \mathrm{O}_{3}$ coatings' deposition. Here $P$ is power capacity of plasma generator, $G$ total flow rate of plasma forming gas, $G\left(\mathrm{H}_{2}\right)$ flow rate of additional gas or hydrogen, $T$ mean-mass gas temperature, $X$ spraying distance, $V$ mean-mass gas velocity.

\begin{tabular}{lccc}
\hline Regime & $I$ & $I I$ & $I I I$ \\
\hline$P, \mathrm{~kW}$ & 49 & 49 & 49 \\
$G, \mathrm{~g} \mathrm{~s}^{-1}$ & 5.5 & 5.5 & 5.5 \\
$G\left(\mathrm{H}_{2}\right), \mathrm{g} \mathrm{s}^{-1}$ & 0 & 0.1 & 0.15 \\
$T, \mathrm{~K}$ & 2700 & 3400 & 3770 \\
$X, \mathrm{~mm}$ & 70 & 70 & 70 \\
$V, \mathrm{~m} / \mathrm{s}$ & 1000 & 1400 & 1580 \\
\hline
\end{tabular}

lected into distilled water. These granules can be industrially used as high temperature insulating material.

Other primary data (determined by experiments) are as follows: flow outlet nozzle diameter $d=10-2 \mathrm{~m}$; the diameter of particles $50-70 \mu \mathrm{m}$; the exhaust jet is surrounded by air of unrestricted space. The computing domain is a cylinder-shaped space covered with a set of meshes of a grid. The diameter of the computing domain is $200 \mathrm{~mm}$ and the total number of variable size geometrical grids is approximately 300000 . This is described in detail in [11].

\section{Results}

After mixing with plasma jet, solid particles need some time to heat and at the start their temperature is lower than the temperature of plasma gas. Particles are small-sized and quickly heat up; they are heated in plasma jet by convection, whereas inside particles the 


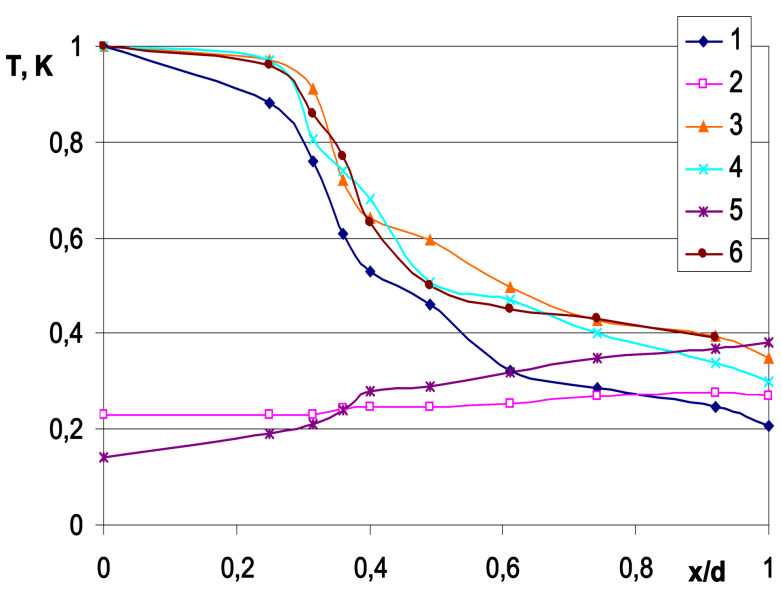

Fig. 2. Nondimensional distributions of plasma temperature $(1 \mathrm{cal}-$ culated with "Jets\&Poudres" by other authors [12], 3 our experimental research, 4 calculated with "Jets\&Poudres", 6 calculated by other authors using other numerical models [11]) and ceramic $50 \mu \mathrm{m}$ particles' temperature ( 2 calculated with "Jets\&Poudres" by other authors [12], 5 our calculation with "Jets\&Poudres").

heat is transferred by conduction. As it can be seen from Fig. 1(a), the temperature of dispersed particles near substratum surface exceeds average temperature of gas jet and is $1200-1600 \mathrm{~K}$.

As can be seen from Fig. 1(b), velocity of dispersed particles near the covering surface exceeds average gas jet velocity and depending on the sizes of particle reaches $150-320 \mathrm{~m} \mathrm{~s}^{-1}$. The smallest particles achieve higher speed than bigger ones, so, the deciding factor of velocity changes is resistance force. The velocity of particles stabilizes at a dimensionless distance $x / d=7$ and then the size of particles has almost no significance. The surface of substratum at the distance $x / d=8-12$ would be hit by stable force of the jet stream and the value of kinetic energy is ultimate. Figure 2 represents the proportional distribution of plasma jet and dispersed ceramic particles temperatures, measured or calculated by different authors $[12,13]$. The trajectories of plasma flow are very similar and have a near agreement. Some differences at the end of travel distance can be observed. Disagreement occurs due to different experimental setup operating conditions, numerical simulation options, and plasma spraying process regimes.

Variation of curve Reynolds number (Re) along flow axis is presented in Fig. 3. In our case, for the regime $I$ in Table 1 the value of $R e$ varies from 2 to 12 . The largest value of $\mathrm{Re}$ is found near the outlet. Since jet mixes with the ambient air and is interrupted, flow becomes unstable. Further the gas in the jet cools down and slightly stabilizes itself. At a distance $x / d=3$ from exhaust nozzle, Re value slightly increases since in this period the jet is slightly disturbed. At this mo-

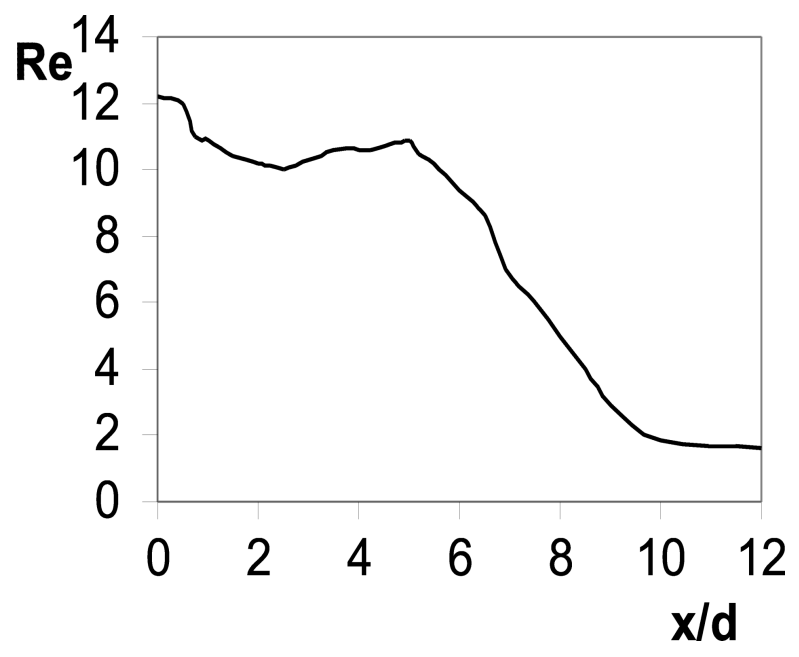

Fig. 3. Variation of Reynolds number along spraying distance.

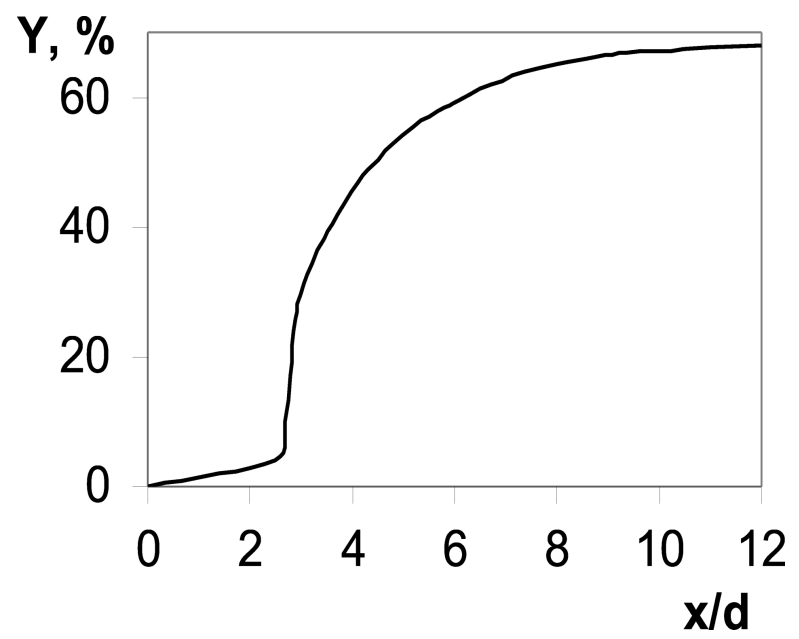

Fig. 4. Dependence of melting degree of $50 \mu \mathrm{m} \mathrm{Al}{ }_{2} \mathrm{O}_{3}$ particle from spraying distance.

ment a very intense melting of particles occurs and recirculation zone appears. At $x / d=8-9$ from exhaust nozzle a particle does not melt anymore and flow stabilizes, whereas Re number obtains a steady value. Intensity of particle's melting $(Y, \%)$ in jet depending on travel distance along flow axis is presented in Fig. 4. The interaction between high temperature jet and injected particles begins immediately. The particle, injected into plasma jet, passes three main flow zones until it reaches a fixed substratum: heating of the particle, its melting, and stable flow. As can be seen from results, initial heating period of the particle continues to $x / d=2.7-3$. During this time the largest part of plasma energy is used for heating the particle. When particle is heated up, it begins to melt due to physical and chemical conversions inside it. Temperature of particle gradually rises and melting rapidly proceeds. The most rapid melting occurs at distance $x / d=3-8$ from 


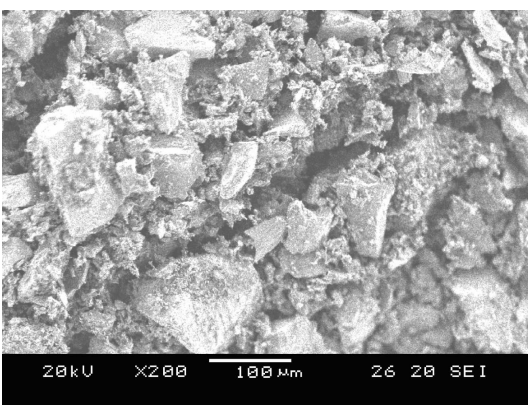

(a)

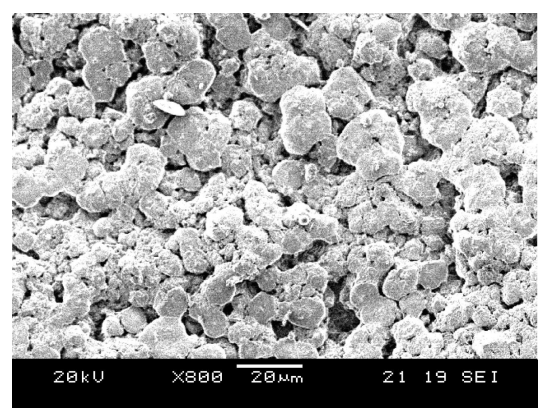

(b)

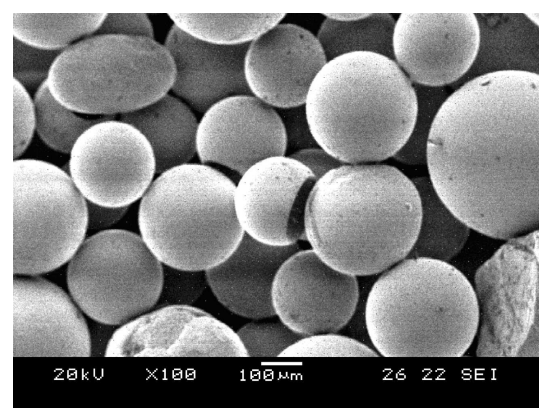

(c)

Fig. 5. SEM micrographs of (a) initial powder and after passing through the plasma jet: (b) at $x / d=3.5-4$ from outlet nozzle, (c) the granules produced at $x / d=10$ from outlet nozzle.

exhaust nozzle and this is the second - melting zone of particle. The practical usability of calculation results has been verified by comparing the simulation data with experiments $[14,15]$. Morphologies of plasmasprayed $\mathrm{Al}_{2} \mathrm{O}_{3}$ powders during the II regime (Table 1) are shown in Fig. 5. As observed by scanning electron microscopy, the initial powder is in the form of

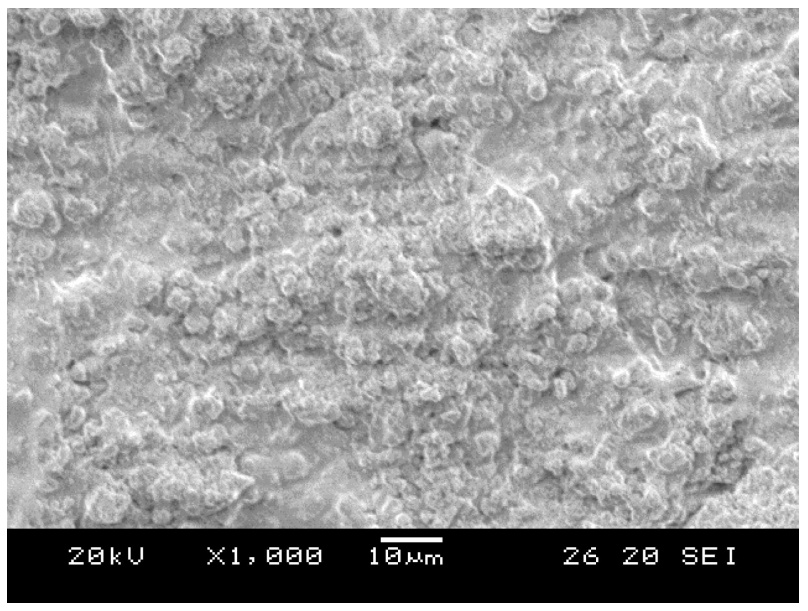

(a)

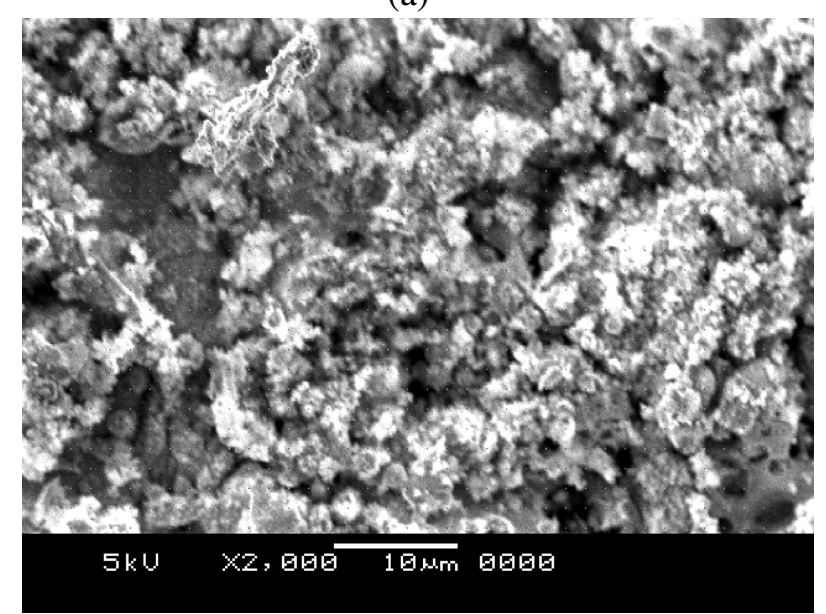

(c) agglomerates with wide size distribution. To determine the melting degree, shape, and size of sprayed particles, they have been collected into distilled water at different distances from outlet nozzle. After passing $x / d=$ 3.5-4, the particles appear partially melted (Fig. 5(b)). During the melting of initial particles of $100 \mu \mathrm{m}$ in diameter the plasma spray pyrolysis process occurred.

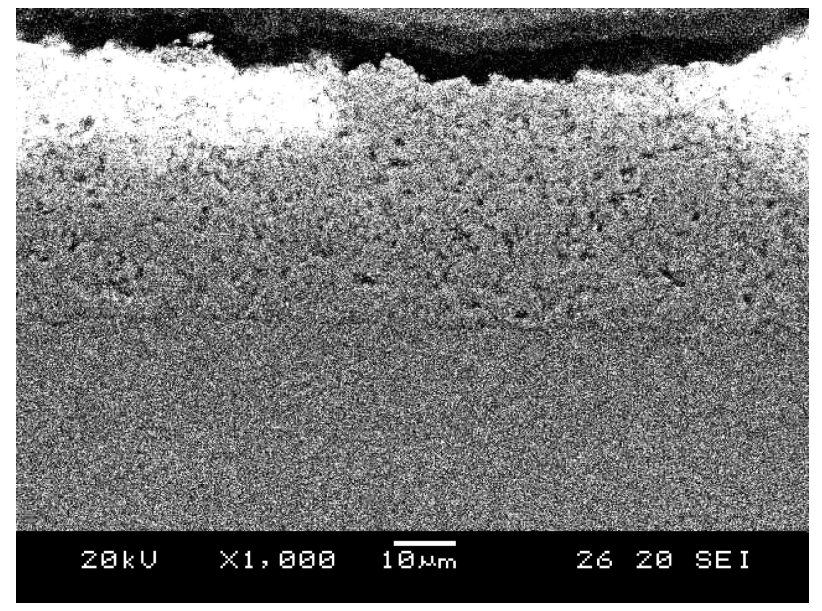

(b)

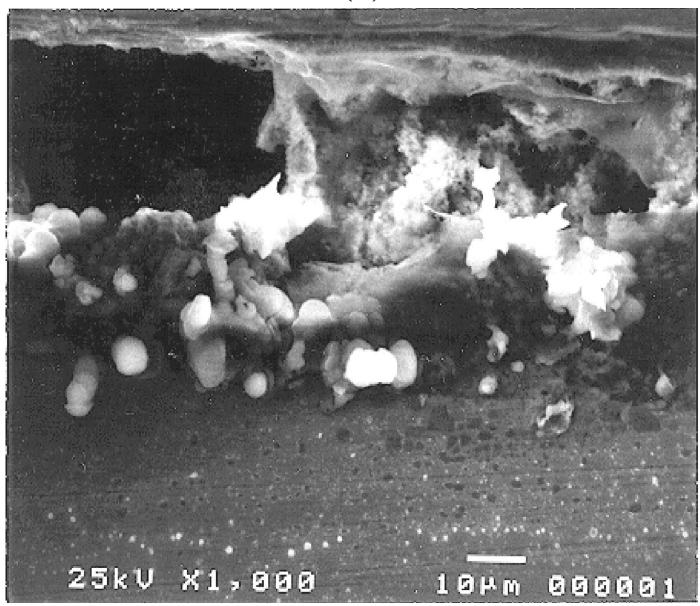

(d)

Fig. 6. SEM micrographs of dense and porous plasma sprayed alumina coatings: (a, c) surface morphology, (b, d) cross-section pictures. 
Dispersed particles of $\mathrm{Al}_{2} \mathrm{O}_{3}$ injected into arc column showed a very fast bulk melting and then very fast particle surface cooling. Further from plasma torch nozzle to the substratum the particles turn into very large granules with the diameter of 150-200 $\mu \mathrm{m}$ (Fig. 5(c)). When the coatings are produced, particles resolve into small fragments on their way and splash on the surface of substratum. Sharp edges of particles become round and the surface of coating becomes fine and smooth (Fig. 6). Applying the $I$ regime of plasma generator (see Table 1) and regulating the working gas flow, PG arc current, spray distance, and at initial diameter of 30 $50 \mu \mathrm{m}$ of dispersed particles, the porous coatings with large free surface for catalytic application (Fig. 6(c, d)) are obtained. Applying the $I I I$ regime, dense thin films for protective purposes could be deposited (Fig. 6(a,b)). In the latter case the plasma spray pyrolysis effect has occurred and initial dispersed particles have broken up into a large amount of fragments. Consequently the grains of plasma sprayed coatings were smaller than $5 \mu \mathrm{m}$.

\section{Conclusions}

Plasma spraying technology at atmospheric pressure offers the possibility to obtain micro-sized particles, granules, and coatings from inorganic metal oxides with controlled characteristics for special application. Plasma jet-particle interaction lasts for about $1.2 \mathrm{~ms}$ and strongly depends on jet temperature, velocity, and particle's mass.

While moving in a jet, the ceramic particle is heated, melted, and splats on the substratum. The most intense melting of particles occurs at $x / d=3-8$ from exhaust nozzle.

Velocity of the particle near the substrate exceeds average plasma jet velocity and depending on the diameter of particle reaches up to $150-320 \mathrm{~m} \mathrm{~s}^{-1}$. At $x / d=8-$ 12 from exhaust nozzle the dispersed particles' flow is steady, whereas the value of kinetic energy is ultimate.

The numerical calculation data shows that the applied numerical model of two-phase high temperature jet calculation is in good agreement with experimental data and could be used to determine the optimal plasma spray parameters for coatings with desirable characteristics. The grain size of plasma sprayed coatings is smaller than $5 \mu \mathrm{m}$.

\section{Acknowledgements}

Authors express their sincere appreciation to Prof. P. Fauchais and his associates for free access to computation programm "Jets\&Poudres".

The authors acknowledge with appreciation the support for this research by the Lithuanian State Science and Studies Foundation and Agency for International Science and Technology Development Programmes in Lithuania.

\section{References}

[1] P. Fouchais, G. Montavon, M. Vardelle, and J. Cedelle, Developments in direct current plasma spraying, Surf. Coatings Technol. 201, 1908-1921 (2006).

[2] K. Landes, Diagnostics in plasma spraying techniques, Surf. Coatings Technol. 201, 1948-1954 (2006).

[3] M. Garbero, M. Vanni, and U. Fritsching, Gas / surface heat transfer in spray deposition processes, Int. J. Heat Fluid Flow 27, 105-122 (2006).

[4] F.B. Yeh, The effect of plasma characteristics on the melting time at the front surface of a film on a substrate: An exact solution, Int. J. Heat Mass Transfer 49, $297-$ 306 (2006).

[5] H. Kersten, H. Deutsch, H. Steffen, G.M.W. Kroesen, and M. Hippler, The energy balance at substrate surfaces during plasma processes, Vacuum $\mathbf{6 3}, 385-431$ (2001).

[6] G. Delluc, G. Mariaux, A. Vardelle, P. Fauchais, and B. Pateyron, A numerical tool for plasma spraying. Part I: Modeling of plasma jet and particle behavior, in: $A b$ stracts and full paper CD of the ISPC 16, Taormina, Italy, June 22-27, 2003, 6 p.

[7] T\&TWinner can be download from http://ttwinner.free.fr .

[8] R. Kèželis, P. Valatkevičius, and A. Ambrazevičius, Velocity and temperature distribution in the entrance region of tube with high temperature turbulent air flow, Trudy Akademii Nauk Litovskoy SSR B 6(97), 57-61 (1976) [in Russian].

[9] V. Valinčius, P. Valatkevičius, and L. Marcinauskas, Preparation of hard coatings employing nonequilibrium plasma under atmospheric and reduced pressure, in: 16th International Symposium on Plasma Chemistry ISPC-16: Proceedings, Taormina, Italy, June 22-27, 2003 (University of Bari, Italy, 2003) pp. 1-6.

[10] V. Valinčius, V. Krušinskaitè, P. Valatkevičius, V. Valinčiūtè, and L. Marcinauskas, Electric and thermal characteristics of the linear, sectional DC plasma generator, Plasma Sources Sci. Technol. 13, 199-206 (2004).

[11] V. Valinčiūtè, Research on Plasma Spray Pyrolysis in the Processes of Coatings Synthesis, Summary of the 
doctoral dissertation (Kaunas University of Technology, 2007).

[12] G. Delluc, H. Ageorges, B. Pateyron, and P. Fauchais, Fast modelling of plasma jet and particle behaviours in spray conditions, High Temp. Mater. Processes 9, 211226 (2005).

[13] T. Klocker, M. Dorfmann, and T.W. Clyne, Process modelling to optimise the structure of hollow zirconia particles for use in plasma sprayed thermal barrier coatings, in: ITSC 2001, eds. C.C. Berndt, K.A. Khor, and
E.F. Lugscheider (ASM, Singapore, 2001) pp. 149155.

[14] P. Valatkevičius, V. Krušinskaitè, V. Valinčiūtė, and V. Valinčius, Preparation of catalytic coatings for heterogeneous catalysts employing atmospheric pressure non-equilibrium plasma, Surf. Coatings Technol. 174175, 1106-1110 (2003).

[15] K. Brinkiene and R. Kezelis, Effect of alumina addition on the microstructure of plasma sprayed YSZ, J. Eur. Ceram. Soc. 25, 2181-2184 (2005).

\title{
DVIFAZIO PLAZMOS SRAUTO MATAVIMAI IR SKAITMENINIS MODELIAVIMAS PLAZMINIO PURŠKIMO PROCESE
}

\author{
V. Grigaitienè, V. Valinčius, R. Kèželis
}

Lietuvos energetikos institutas, Kaunas, Lietuva

\section{Santrauka}

Skaitmeniniai dvifazio plazmos srauto tyrimai buvo atlikti naudojant „Jets\&Poudres“ programą, kuri yra specialiai pritaikyta modeliuoti plazmos srauto tekejjimą bei joje vykstančius procesus. Gauti dvifazio srauto modeliavimo rezultatai palyginti su eksperimentiniais duomenimis. Eksperimentini plazminio purškimo įrengini sudaro dispersinių dalelių maitinimo ir dozavimo sistema bei linijinis nuolatinès srovès $30-40 \mathrm{~kW}$ galios plazmos generatorius (PG) su karštu katodu ir laiptuotu anodu. I aukštos temperatūros srautą tiekiamos ịvairios medžiagos ar jų mišiniai: anglis, kaolinas, aliuminio, vario, cirkonio oksidai ir kt. Nustatyta, kad dispersinių dalelių temperatūra ties $x / d=8-12$ viršija vidutinę dujų temperatūrą ir yra 1200-1600 K. Tiriant dalelių greičio kitimus priklausomai nuo nuskrieto atstumo, galima pastebèti, kad mažiausios dalelès per tą patị laiką pasiekia didesni greitị. Dalelių greitis stabilizuojasi ties $x / d=8$ nuo PG ištekejimo angos ir beveik nepriklauso nuo jų dydžio. Tai rodo, kad paruoštas dengiamas substratas ties $x / d=8-12$ bus bombarduojamas pastoviu jègos impulsu, dalelių kinetinè energija bus maksimali. Gauti rezultatai parodè, kad skaitmeninio modeliavimo rezultatai neblogai sutampa su eksperimentų duomenimis, todèl gali būti naudojami nustatant optimalius plazmos purškimo parametrus, gaminant pageidaujamu savybių dangas. 